\title{
J-DEPACE
}

JOURNAL OF DEDICATION TO PAPUA COMMUNITY JURNAL PENGABDIAN MASYARAKAT

JURNAL PENGABDIAN

ISSN : 2654-8356(Onfine), ISSN : 2655-1799(Print)

J-DEPACE, Volume 3, Nomor 1, Juni 2020, Hal 178-188

Tersedia online di :http://jurnal.lpmiunvic.ac.id/index.php/jpkm

\section{PENGGUNAAN MEDIA GAMBAR UNTUK MENINGKATKAN KEMAMPUAN ANAK DAN REMAJA DALAM KOSAKATA BAHASA INGGRIS DI JEMAAT MARANATHA KAMPUNG SAYOSA KABUPATEN SORONG}

\author{
Peter Manuputty ${ }^{1 *}$, Juneth N Wattimena ${ }^{2}$ \\ Fakultas Keguruan dan Ilmu Pendidikan Universitas Victory Sorong \\ Fakultas Ilmu Komputer Universitas Victory Sorong \\ petermanuputty3@gmail.com ${ }^{1 *},{ }^{2}$ junethwattimena@gmail.com
}

\begin{abstract}
ABSTRAK
Kosakata dalam bahasa inggris merupakan hal penting untuk dipelajari dan diingat bagi setiap orang yang ingin mempelajarinya. penguasaan kosakata dapat membuat orang bisa mendengar, berbicara, membaca dan menulis dalam bahasa inggris. orang juga dapat pergi keliling dunia hanya dengan menguasai bahasa inggris karena adalah bahasa internasional. anak anak dan remaja di jemaat maranatha, kampung sayosa, kabupaten sorong, sebagian besar masih belum menguasai kosakata dalam bahasa inggris seperti membaca huruf dalam bahasa inggris, membaca angka dalam bahasa inggris, mengenal bagian bagian tubuh manusia dan bagian bagian dari rumah. metode yang digunakan dalam kegiatan pengabdian ini adalah media gambar dan tahapan pengajaran terdiri dari studi pendahuluan, pemaparan materi dan evaluasi. kesimpulan dari kegiatan pengabdian ini adalah anak anak dan remaja dapat mudah mengerti dan sangat bersemangat mengikuti materi yang bertujuan untuk meningkatkan kosakata menggunakan metode gambar.
\end{abstract}

Kata Kunci : Media, Gambar, Kosakata Bahasa Inggris

\section{ABSTRACT}

The vocabulary in English is an important thing to learn and remember for everyone who wants to learn it. The mastery of vocabulary can enable people to hear, speak, read and write in English. The people can also go around the world just by mastering English because it is an international language. Most of the children and adolescents in the Maranatha congregation, Sayosa village, Sorong Regency, mostly still do not master English vocabulary such as reading letters in English, reading numbers in English, recognizing human body parts and parts of the house. The method used in this service activity is picture media and the teaching stages consist of preliminary studies, material presentation and evaluation. The conclusion from this service 
activity is that children and adolescents can easily understand and are very enthusiastic about following the material that aims to increase vocabulary using the picture method.

\section{Keyword : Picture, Media, English Vocabulary}

\section{INTRODUCTION}

English is the international language in the world. English is the bridge to communicate about everything between someone with another someone or between a group with another group from different country. The subject of English has been taught at every school, it begins from kindergarten, elementary school, junior high school, senior high school until at the college in Indonesian. In Sorong regency, English has been taught at elementary school education grade. It is not only at school that English can be studied, but can be studied anymore at course place, at home, and everywhere.

So many people can not understand English well in Indonesia especially in Sorong regency, even English becomes a dreaded specter to learn because it is a foreign language. English is very important to be studied from childhood as the foundation for the child. There are four skills to be learned in English, such as listening, speaking, reading and writing.

It is important for English teachers to encourage and motivate students to learn and love English. In this time the English teacher are still getting difficulty deciding what techniques and media to use in English and how to teach English properly. In this regard the teachers have the responsibility to guide children during the learning process and provide the motivation for them to improve English. To overcome the problem, there are many teaching that can help teachers deliver the material so that they can readily understand the material that is taught.

The community service team saw and felt the need to motivate the children of Sayosa Maranatha Sunday school at Sayosa regency to know and love English so that it will be easy and fun to be learned. This is important in order to become accustomed and have fun experiences in learning English, so that when they continue to educational stools or to higher levels, they can have good English education and basic experiences. The children of Sayosa Maranatha Sunday school in Sorong Regency are chosen by the team as a representation of a place in Sorong and it is expected that community service can also be performed elsewhere.

Sabri (2010:110) said that "picture is a number of pictures, photos, and painting from 
book, newspaper or another source that can be used as teaching aid".

Arum Wahyuningsih (2011). She describes about Students' Writing Skill through Picture Media in Grade X of office Administration 2 of SMK Negeri 1 Tempel. The result of her study indicated that the process of teaching and learning accompanied with pictures could lead the students' motivation in writing and their skill improvement. The community service team realizes that using media enables the children to be actively involved in the learning process. One media that can assist in delivering the material dealing with the vocabulary is the picture. Using the picture media can help the children to understand English words, so that this service to society is entitled 'Using Picture Media to Improve Children and Adolescent's Ability on Vocabulary at Maranatha Congregation of Sayosa Village in Sorong Regency.

\section{FORMULATION OF PROBLEM}

The formulation of problem in service of society is how to increase the children vocabulary and children interest in learning English?

\section{METHODOLOGY}

The method is used in this service to society is public education method. Kateřina Joklová (2009) "observed about using pictures in teaching vocabulary". In her research, she found the main goal of this thesis was to show how pictures can be put to use in English classes in a few ways and to answer the questions how and why this works and in what way exactly they help the learner remember the words he or she studies. The method used here is the picture media that it is purpose to improve children and adolescent's ability on vocabulary at Maranatha Congregation of Sayosa Village in Sorong Regency. Mackey (2005) "mentioned media likes picture, movies or songlyric are usually most often used as a tool to learn". It means tool that teacher used in classroom can be able to manipulate to seen, to hear and to read in order to facilitate teaching in the class.

\subsection{Pre-Activity (Pre-Interview)}

The first step before doing the teaching, our team has the interview about the problem of English vocab and the way out to overcome. The interviews are conducted for parents and children. The purpose of interview is to know the reality of the children ability in 
vocabulary. That is why, our team has to do this teaching the material about the vocabulary with using picture media method.

\subsection{Main Activity}

There are the material stages which are presented in this service to society about Using Picture Media to Improve Children and Adolescent's Ability on Vocabulary at Maranatha Congregation of Sayosa Village in Sorong Regency. They are as follow:

a. Reading the alphabet in English

b. Reading the numeral in English

c. The parts of body

d. The parts of home's room

This is a schedule of the activity about using picture media to increase the vocabulary of children. The schedule is as in below:

Table 3.2

Schedule of Service to society

\begin{tabular}{|l|c|l|}
\hline Day/Date & Hour & Activity \\
\hline lay, March $27^{\text {th }} 2020$ & $08.00-08-30$ & Registration of Member \\
\hline & $08.30-10.00$ & Pre Activity \\
\hline & $10.00-12.00$ & Teaching Material \\
\hline & $12.00-13.00$ & Break Time \\
\hline & $13.00-14.30$ & Post Activity \\
\hline & $14.30-$ Finish & Closing \\
\hline
\end{tabular}

\subsection{Post Activity (Post-Interview)}

There is also a technique where used to measure how far children's understanding and knowledge about basic grammar, we called as post interview. This step is the way to compare with pre-interview after getting the material presentation. As to the comparison between pre-interview and after getting the material presentation so can be known how far the children's understanding and knowledge about basic grammar. 
By using the post interview, you can compare the initial test and the provision of material with the post test, so you can find out the comparison or improvement of each child from the pre test to the post test.

\section{FINDINGS AND DISCUSSION}

Teaching to the children at Maranatha Congregation of Sayosa Village in Sorong Regency about using picture media to improve children and adolescent's ability can be done in some stages. They are as follow:

\subsection{English Alphabet}

The modern English alphabet is a Latin alphabet consisting of 26 letters, each having an upper and lower case form. It originated around the 7th century from Latin script. Since then, letters have been added or removed to give the current Modern English alphabet of 26 letters.

Picture 4.1

\section{English Alphabet}

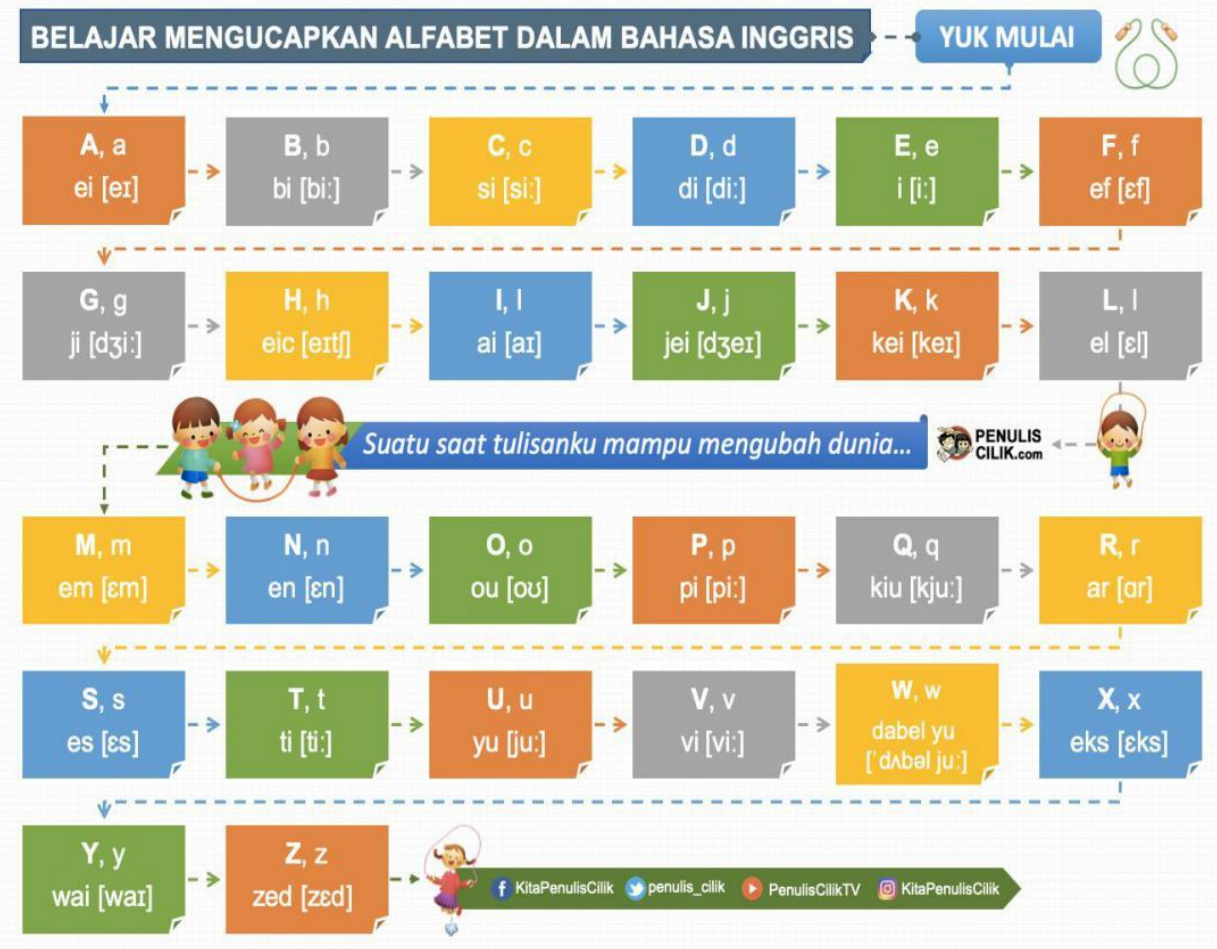


The alphabet is the basis for learning to read for everyone. When we have learned to read the letters and recognize them, so we can read letter to letter, word to word, sentence to sentence until can read a story text. The service team to society in the third section gives the children the material about reading the alphabet so that they become more proficient in reading.

\section{Picture 4.2}

\section{Teaching Process}

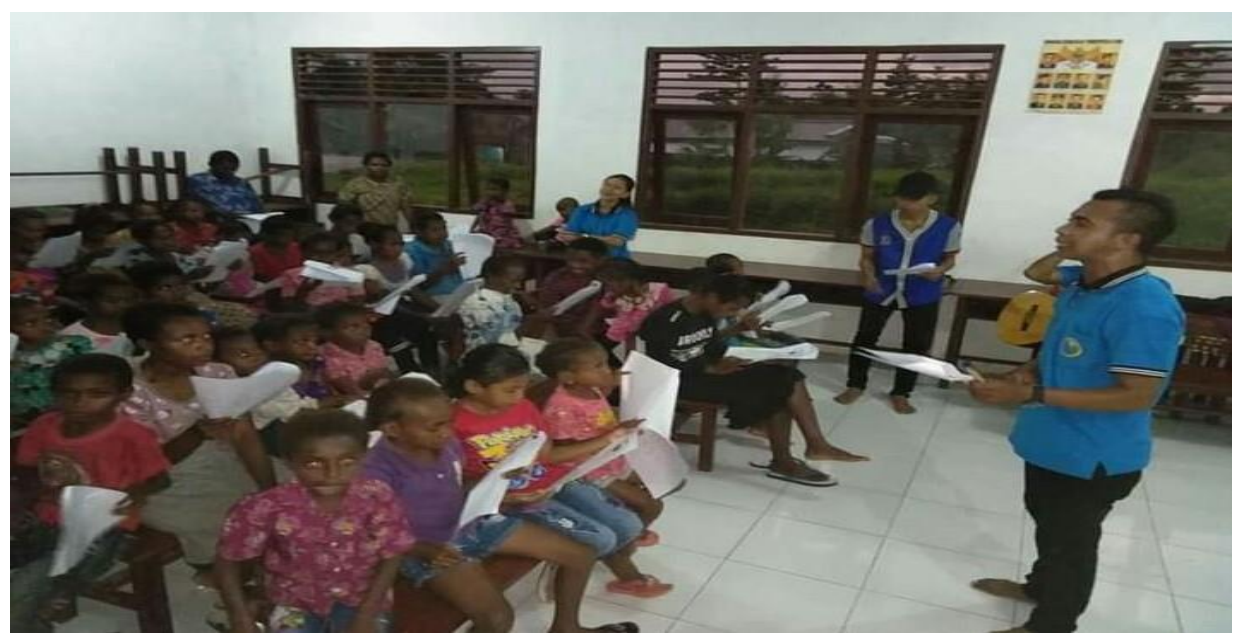

\subsection{English Numeral}

In linguistics, a numeral (or number word) in the broadest sense is a word or phrase that describes a numerical quantity. Some theories of grammar use the word "numeral" to refer to cardinal numbers that act as a determiner to specify the quantity of a noun, for example the "two" in "two hats". Some theories of grammar do not include determiners as a part of speech and consider "two" in this example to be an adjective. Some theories consider "numeral" to be a synonym for "number" and assign all numbers (including ordinal numbers like the compound word "seventy-fifth") to a part of speech called "numerals". Numerals in the broad sense can also be analyzed as a noun ("three is a small number"), as a pronoun ("the two went to town"), or for a small number of words as an adverb ("I rode the slide twice"). "collective numeral" redirects here. It is not to be confused with collective number or collective noun.

Many words of different parts of speech indicate number or quantity. Such words are 
called quantifiers. Examples are words such as every, most, least, some, etc. Numerals are distinguished from other quantifiers by the fact that they designate a specific number, examples are words such as five, ten, fifty, one hundred, etc. They may or may not be treated as a distinct part of speech; this may vary, not only with the language, but with the choice of word. For example, "dozen" serves the function of a noun, "first" serves the function of an adjective, and "twice" serves the function of an adverb

\section{Picture 4.3}

\section{The Numeral In English}

\begin{tabular}{|c|c|c|c|c|}
\hline$\frac{\ddot{x}}{\text { One }}$ & $\frac{2}{T=0}$ & There & $\underset{\text { Four }}{n}$ & $\frac{91}{a i v e}$ \\
\hline$\frac{B}{5 x}$ & ${ }_{\text {seven }}^{28}$ & Esht & $\sum_{\text {Nane }}^{8}$ & $\frac{29}{\operatorname{ten}}$ \\
\hline $\begin{array}{c}11 \\
\text { Elenen }\end{array}$ & Twelve & $\frac{13}{\text { Thirteien }}$ & Forrees & $\begin{array}{l}15 \\
\text { Fif rees }\end{array}$ \\
\hline $\begin{array}{l}16 \\
\text { sxtheen }\end{array}$ & $\begin{array}{c}17 \\
\text { swenteen }\end{array}$ & $\begin{array}{l}18- \\
\text { Eughteen }\end{array}$ & $\begin{array}{c}\text { 1S] } \\
\text { rinetrees }\end{array}$ & $\begin{array}{l}20 \\
\text { Twenty }\end{array}$ \\
\hline Zero & Twenfy-ank: & $\frac{30}{\text { Thirty }}$ & $\begin{array}{l}\text { ADD } \\
\text { rorty }\end{array}$ & $\frac{0.8}{\text { rifry }}$ \\
\hline $\begin{array}{c}60 \\
\text { sionty }\end{array}$ & Seventy & $\frac{290}{\text { Eaghty }}$ & nolly & $\begin{array}{c}400 \\
\text { One handred }\end{array}$ \\
\hline 1000 & 1.0 & 00 & 1. 000 & 0.000 \\
\hline
\end{tabular}

material about numbers in English is taught by the community service team to children because numbers are important things in human life such as counting money or making purchases and sales of an item, of course there are transactions regarding the price of these items and there are many more benefits.

\subsection{The Parts of Body}

Human body parts are something that can not be separated from the body. The community service team began teaching the vocabulary by using pictures of human body parts so that children could understand and enjoy the teaching of vocabulary. 
Body language is a type of a nonverbal communication in which physical behaviors, as opposed to words, are used to express or convey the information. Such behavior includes facial expressions, body posture, gestures, eye movement, touch and the use of space. Body language exists in both animals and humans, but this article focuses on interpretations of human body language. It is also known as kinesics.

\section{Picture 4.4}

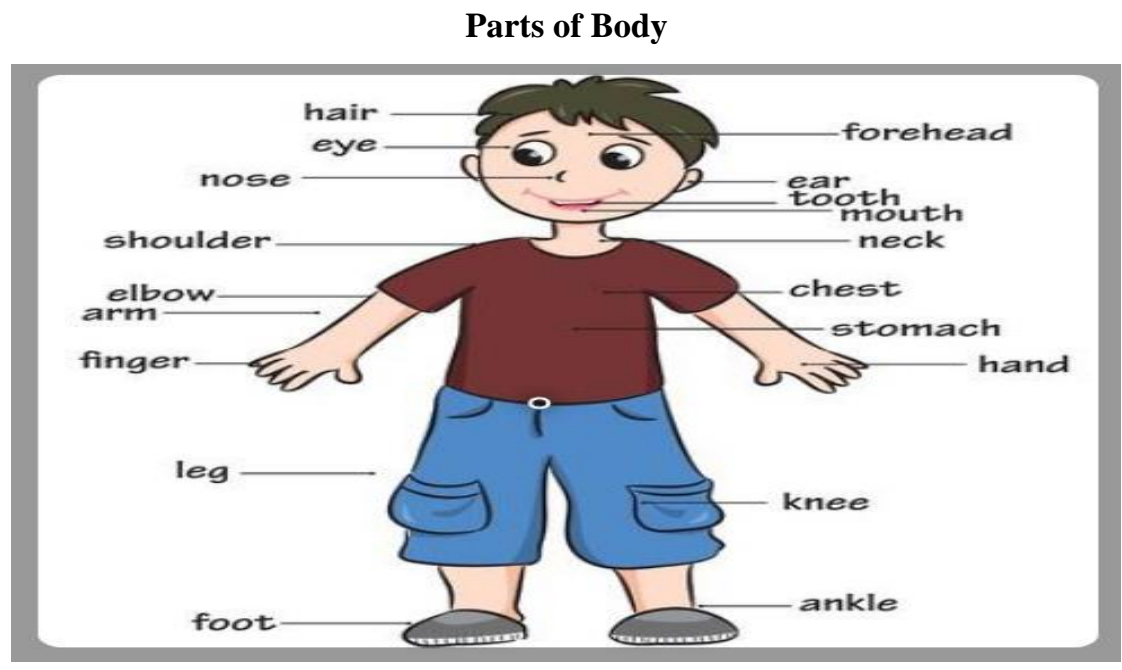

The translation of vocabularies in Indonesian as below:

1. Hair : Rambut

2. Forehead : Dahi

3. Ear : Telinga

4. Eye : Mata

5. Nose : hidung

6. Mouth : Mulut

7. Tooth : Gigi

8. Neck : Leher

9. Shoulder : Bahu/Pundak

10. Elbow : Siku

11. Chest : Dada

12. Lengan : Arm 
13. Stomach : Perut

14. Finger : Jari

15. Hand : Tangan

16. Thigh : Paha

17. Leg/Foot : Kaki

18. Knee : Lutut

19. Ankle : Pergelangan Kaki

\subsection{Parts of Home}

The home is a human residence and it is the most important place for human being because they can rest when tired and can also protect from rain and heat. The people will have a lot of time to be in the house, for that the community service team makes the next material using the part of house to improve children's vocab.

Picture 4.5

Part of House

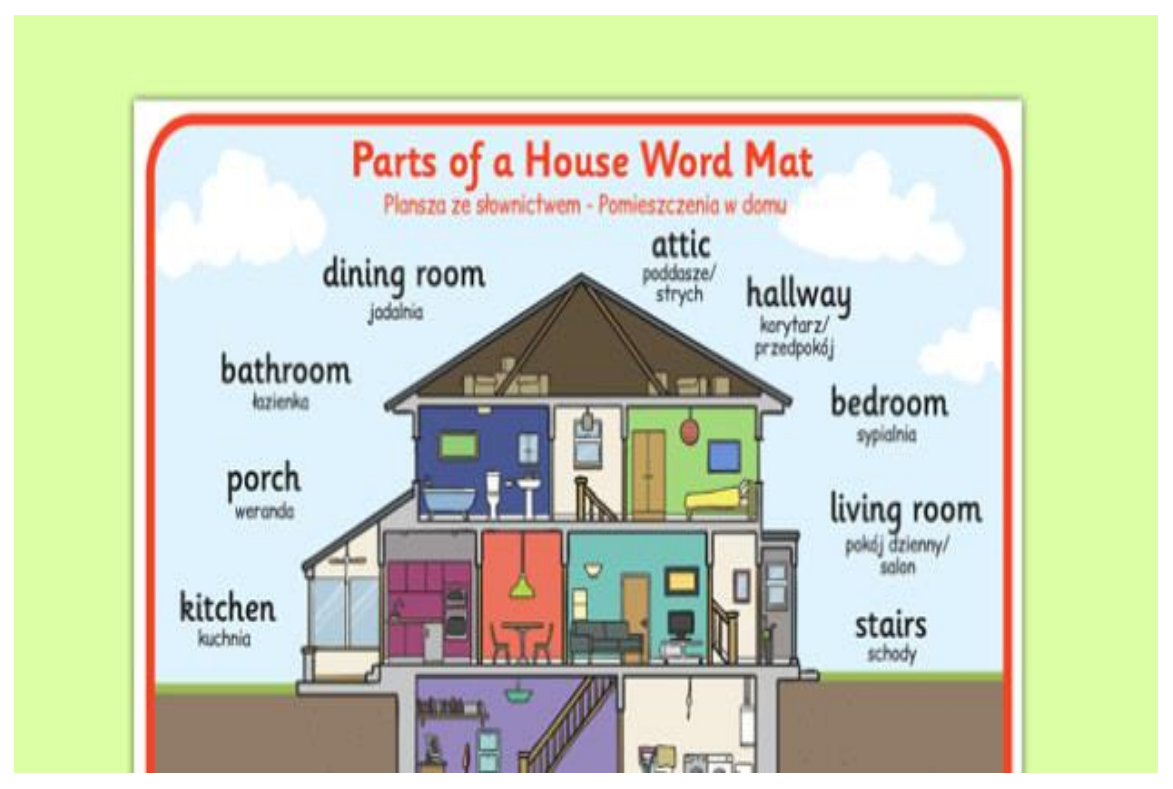

The translation of vocabularies in Indonesian as below:

1. Bed Room : Ruang Tidur

2. Bath Room : Kamar Mandi

3. Porch : Serambi 

4. Dining Room : Ruang Mandi
5. Attic : Loteng
6. Hallway : Lorong Masuk
7. Living Room : Ruang Tamu
8. Stairs : Tangga
9. Kitchen : Dapur

Picture 4.6

Teaching Process

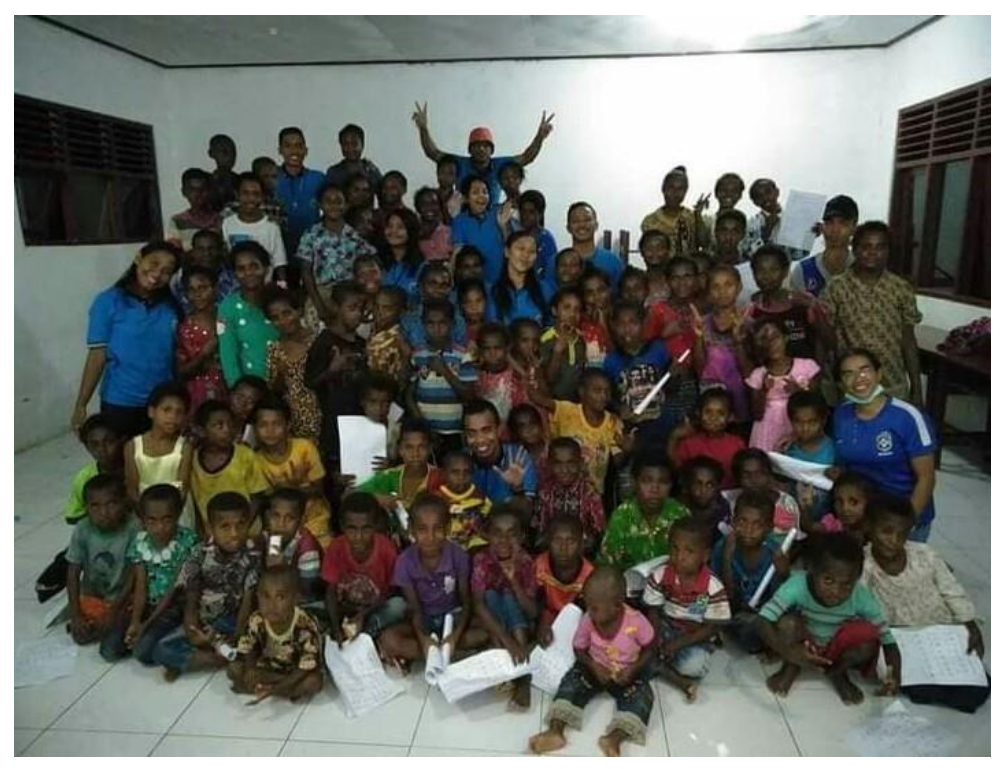

\section{CONCLUSION}

After the community service team taught the children with the material that had been provided, we saw that they were very enthusiastic in following each material and they also found it easy to learn vocabulary using pictures because they could see the pictures directly so they could guess what was going on. they see and after that learn to say what they see using English. We as a community service team feel happy to see that they are enthusiastic and easy to understand in the learning process, therefore using image media can improve the English vocabulary of children and adolescent at Maranatha Congregation of Sayosa Village in Sorong Regency. 


\section{REFERENCES}

Sabri, A. (2010). Strategi Belajar Mengajar; Microteaching. Jakarta: Quantum Teaching.

Wahyuningsih, A. (2011). Improving Students` Writing Skill through Picture Media.Thesis. Faculty of Language and Arts Yogyakarta: State University of Yogyakarta

Joklova, K. (2009). Using Picture in Teaching Vocabulary. Thesis. Czechia: Masaryk University

Mackey A., \& Gass,S.M. (2005). Second Language Research: Methodology and Designed. New Jersey: Lawrence Erlbaum Associates 